\title{
Morphology External Filename
}

National Cancer Institute

\section{Source}

National Cancer Institute. Morphology External Filename. NCI Thesaurus. Code $C 117618$.

The literal identifier of an morphology external file name. 